\title{
PENGARUH PENERAPAN SISTEM INFORMASI AKUNTANSI TERHADAP KUALITAS LAPORAN KEUANGAN
}

\author{
Rio Gusherinsya ${ }^{1}$, Samukri ${ }^{2}$ \\ ${ }^{1}$ STIE Muhammadiyah Jakarta, rio2308gus@gmail.com \\ ${ }^{2}$ STIE Muhammadiyah Jakarta, Samukri81@gmail.com
}

\begin{abstract}
ABSTRAK
Penelitian ini bertujuan untuk mengetahui pengaruh penerapan sistem informasi akuntansi terhadap kualitas laporan keuangan pada PT. CSM Cargo. Pendekatan penelitian yang digunakan dalam penelitian ini adalah analisis deskriptif dan kausalitas dengan menggunakan data primer. Teknik sampling yang digunakan adalah non probability sampling dengan memakai sampel jenuh. Analisis statistic yang digunakan dalam penelitian ini adalah uji analisis regresi linier sederhana, pengujian hipotesis dengan menggunakan uji t. Populasi penelitian ini adalah di bagian administrasi pada PT. CSM Cargo. Sampel penelitian yang digunakan adalah 47 orang dengan sumber data yang diperoleh melalui hasil pengisian kuesioner. Berdasarkan hasil penelitian yang dilakukan dapat diketahui bahwa penerapan sistem informasi akuntansi berpengaruh terhadap kualitas laporan keuangan. Hasil penelitian ini menunjukkan bahwa dengan diterapkannya sistem informasi akuntansi dengan baik dan benar dapat meningkatkan kualitas laporan keuangan.
\end{abstract}

Kata Kunci : Sistem Informasi Akuntansi, Kualitas Laporan Keuangan

\begin{abstract}
This study aims to determine the effect of the application of accounting information systems on the quality of financial statements at PT. CSM Cargo. The research approach used in this research is descriptive analysis and causality using primary data. The sampling technique used is non-probability sampling using saturated samples. The statistical analysis used in this study is a simple linear regression analysis test, hypothesis testing using t test. The population of this research is the administration at PT. CSM Cargo. The research sample used was 47 people with data sources obtained through the results of filling out the questionnaire. Based on the results of research conducted can be seen that the application of accounting information systems affect the quality of financial statements. The results of this study indicate that the application of accounting information systems properly and correctly can improve the quality of financial statements.
\end{abstract}

Keywords : Accounting Information System, Quality of Financial Statement.

Naskah diterima: 22-04-2020, Naskah dipublikasikan: 30-04-2020

\section{PENDAHULUAN}

Pada saat ini, aktivitas perekonomian kita dipermudah oleh keberadaan sistem yang terkomputerisasi. Tak bisa dipungkiri bahwa dalam setiap aktivitas perekonomian kita akan menemukan dan berinteraksi dengan sistem. Sering kali dalam kegiatan bisnis kita akan menemukan sistem informasi akuntansi. Untuk menunjang kegiatan bisnis agar dapat bersaing dengan kompetitor lain dibutuhkan penunjang yang tidak bisa terlepaskan yaitu keperluan data, informasi dan perkembangan teknologi informasi. Maka dari itu penggunaan sistem informasi akuntansi diperlukan untuk mengolah data dan informasi yang telah diperoleh. 
Sampai dengan saat ini masih ditemukan fenomena kurang optimalnya kinerja sistem informasi akuntansi yang ada di Indonesia. Salah satunya terjadi pada PT CSM Cargo dimana masih terdapat keterlambatan dalam penerbitan laporan keuangan bulanan dan tahunan karena baru di kantor jakarta saja yang sudah menggunakan sistem informasi akuntansi yang sesuai standar sedangkan untuk yang di cabang masih menggunakan pembukuan manual. Hal tersebut juga dipengaruhi oleh jumlah sumber daya manusia yang berada di cabang juga sedikit dan latar belakang pendidikan bukan dari background ekonomi yang paham tentang administrasi dan akuntansi (Kepala Bagian Keuangan PT CSM Cargo, Riyanto Saputro)

Penelitian yang dilakukan oleh Sujadijaya (2017) dan Almumtahanah dan Samukri (2019), Salah satu faktor pendukung kualitas laporan keuangan adalah sistem informasi akuntansi. Penelitian tersebut sejalan dengan penelitian yang dilakukan oleh Prasisca (2013) yang membuktikan bahwa penerapan sistem informasi akuntansi keuangan terbukti memiliki pengaruh terhadap kualitas laporan keuangan pada koperasi PT. PLN (Persero) Kota Palembang. Tidak jauh berbeda, penelitian yang dilakukan oleh Soudani (2012) membuktikan bahwa sistem informasi akuntansi yang diterapkan pada perusahaan berpengaruh positif terhadap performa organisasi pada perusahaan terdaftar di bursa pasar di Dubai.

Hal ini bertolak belakang dengan penilitian Mahdi (2010) yang menunjukkan software sistem informasi akuntansi yang ada masih belum mampu meng-improve standar akuntansi di Iran, software sistem informasi akuntansi belum berkaitan dengan sistem keuangan dengan sistem manajerial, sistem informasi akuntansi belum mampu memberikan semua informasi yang dibutuhkan perusahaan, sistem informasi akuntansi belum mampu memberikan informasi kesemua level manajemen, dan sistem informasi akuntansi di masa lalu fokus pada pencatatan, peringakasan, validasi transaksi keuangan organisasi.

Fakta lainnya dimana keberadaan serta pemanfaatan teknologi informasi yang digunakan dalam sistem informasi akuntansi saat ini masih ada yang belum menjamin kualitas laporan keuangan. Penelitian yang dilakukan oleh Tampaty (2017) menunjukkan bahwa pemanfaatan dari pemakaian teknologi informasi menunjukkan hasil berpengaruh negatif dan signifikan terhadap kualitas laporan keuangan pemerintah daerah di satuan kerja perangkat daerah Kabupaten Bondowoso

Berdasarkan pendapat para ahli, fenomena, serta penelitian terdahulu maka peneliti bermaksud untuk melakukan penelitian tentang Pengaruh Penerapan Sistem Informasi Akuntansi Terhadap Kualitas Laporan Keuangan.

\section{KAJIAN PUSTAKA}

\section{Sistem Informasi Akuntansi}

Menurut Susanto (2013:72) sistem informasi akuntansi adalah kumpulan (integrasi) dari sub-sub sistem/komponen baik fisik maupun non fisik yang saling berhubungan dan bekerja sama satu sama lain secara harmonis untuk mengolah data transaksi yang berkaitan dengan masalah keuangan menjadi informasi keuangan.Menurut Gelinas dan Dull (2012:13), sistem informasi akuntansi merupakan sistem yang digunakan untuk mengumpulkan, mengolah, dan melaporkan informasi terkait dengan aspek keuangan akan kegiatan bisnis.

\section{Penerapan Sistem Informasi Akuntansi}

Romney \& Steinbart (2009, hal. 28) berpendapat bahwa Penerapan Sistem informasi akuntansi adalah suatu kesatuan aktivitas, data, dokumen dan teknologi yang keterkaitannya dirancang untuk mengumpulkan dan memproses data, sampai dengan menyajikan informasi kepada para pengambil keputusan di internal organisasi dan eksternal organisasi.

Menurut Puspitawati dan Anggadini (2011:63) penerapan sistem informasi akuntansi secara umum adalah untuk mengolah data transaksi keuangan perusahaan adapun penggunaan yang lebih khusus sebagai berikut :

a. Pembuatan laporan rutin untuk pihak internal dan pihak eksternal;

b. Pendukung utama aktivitas rutin suatu organisasi/entitas; 
c. Pendukung dalam proses pengambilan keputusan;

d. Melaksanakan aktivitas perencanaan dan pengendalian internal.

\section{Laporan Keuangan}

Menurut Thomas (2013:35), menjelaskan pengertian laporan keuangan adalah hasil akhir dari siklus akuntansi yang memberikan gambaran keuangan tentang suatu perusahaan yang secara periodik disusun oleh manajemen perusahaan. Laporan keuangan memiliki sifat historis yaitu membuat angka-angka tentang kinerja dan kondisi keuangan perusahaan pada masa yang telah lalu (historis).Sedangkan menurut Ikatan Akuntan Indonesia (IAI) (2015:2) laporan keuangan adalah bagian dari proses pelaporan keuangan. Laporan keuangan yang lengkap biasanya meliputi neraca, laporan laba rugi, laporan perubahan posisi keuangan (yang disajikan dalam berbagai cara misalnya laporan arus kas atau laporan arus dana), catatan dan laporan lain serta materi penjelasan yang merupakan bagian integral dari laporan keuangan.

\section{Kualitas Laporan Keuangan}

Menurut Fahmi (2013:4) kualitas laporan keuangan adalah mengenai laporan posisi keuangan dan transaksi-transaksi yang dilakukan dan dipertanggungjawabkan oleh suatu entitas pelaporan.

Menurut Pernyataan Standar Akuntansi Keuangan (PSAK) 2015 No. 1 laporan keuangan yang baik memiliki kriteria sebagai berikut:

1. Dapat dipahami

2. Relevan

3. Keandalan

4. Dapat diperbandingkan.

\section{Kerangka Penelitian}

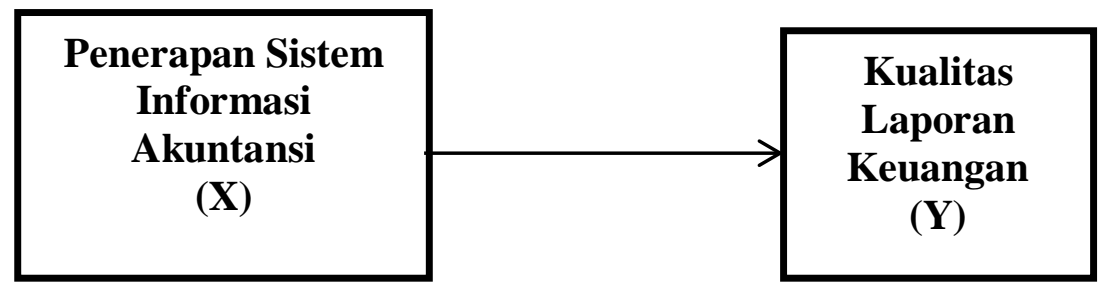

\section{Gambar 1. Kerangka Pikir}

Dalam penelitian Prasisca (2013) menyatakan bahwa sistem informasi akuntansi berpengaruh signifikan terhadap laporan keuangan. Hal itu karena dengan sistem informasi akuntansi dapat memperkecil kesalahan-kesalahan dalam penyajian data akuntansi dan akan menghasilkan laporan yang benar, dan membatasi kemungkinan terjadinya kecurangan.

Hal ini juga diperkuat oleh penelitian yang dilakukan Sujadijaya (2018) serta Almumtahanah dan Samukri (2019) dimana penerapan sistem informasi akuntansi berpengaruh positif terhadap kualitas laporan keuangan.

Dengan demikian hipotesis yang dapat dirumuskan adalah "sistem informasi akuntansi berpengaruh positif terhadap kualitas laporan keuangan”.

\section{METODE PENELITIAN}

Desain penelitian yang digunakan adalah penelitian kausal dengan metode asosiatif dengan pendekatan kuantitatif. Populasi dalam penelitian ini adalah karyawan yang bekerja di bagian administrasi pada PT CSM Cargo. Teknik sampling yang digunakan adalah non probability sampling dengan memakai sampel jenuh. Data primer yang penulis gunakan adalah dari kuesioner yang disebarkan dari anggota-anggota unit kerja yang berhubungan dengan Sistem Informasi Akuntansi dan Kualitas Laporan Keuangan pada PT. CSM Cargo. Pengujian 
hipotesis dengan menggunakan uji t serta uji hipotesis deskriptif. Analisis statistic yang digunakan dalam penelitian ini adalah uji analisis regresi linier sederhana, dengan bentuk umum.

$$
\begin{array}{ll} 
& \mathbf{Y = a + \mathbf { b X }} \\
\text { Keterangan : } & \text { = Subjek nilai dalam variabel terkait yang dipredisikan } \\
\mathrm{Y} & =\text { Harga Y bila X = 0 (harga konstan) } \\
\mathrm{a} & =\text { Angka arah koefisien regresi } \\
\mathrm{b} \quad \text { Subjek pada variabel bebas yang mempunyai nilai tertentu }
\end{array}
$$

Pengujian hipotesis dilakukan dengan membandingkan t-tabel dengan t-statistik, atau membandingkan signifikansi. Jika signifikansi $<0.05$ maka hipotesis penelitian diterima (Wati, 2018)

\section{PEMBAHASAN}

\section{Karakteristik Responden}

Data penelitian diperoleh dengan cara menyebar kuesioner kepada responden yaitu karyawan dan staff administrasi PT CSM Cargo. Kuesioner disebarkan kepada 47 karyawan PT CSM Cargo.

a) Karakteristik responden berdasarkan jenis kelamin

Tabel 1

Kelompok Jenis Kelamin Responden

\begin{tabular}{|l|l|c|c|}
\hline No & Jenis kelamin & Jumlah (orang) & Persentase \\
\hline 1 & Laki - laki & 43 & $91 \%$ \\
\hline 2 & Perempuan & 4 & $9 \%$ \\
\hline & Jumlah & $\mathbf{4 7}$ & $\mathbf{1 0 0} \%$ \\
\hline
\end{tabular}

Sumber : Data kuesioner diolah

b) Karakteristik responden berdasarkan umur responden

Tabel 2

Kelompok Usia Responden

\begin{tabular}{|l|c|c|c|}
\hline No & Kelompok Usia (tahun) & Jumlah (orang) & Persentase \\
\hline 1 & $<25$ & 8 & $17 \%$ \\
\hline 2 & $26-35$ & 32 & $68 \%$ \\
\hline 3 & $36-45$ & 3 & $6 \%$ \\
\hline 4 & $46-55$ & 4 & $9 \%$ \\
\hline & Jumlah & $\mathbf{4 7}$ & $\mathbf{1 0 0 \%}$ \\
\hline
\end{tabular}

Sumber : Data kuesioner diolah

c) Karakteristik responden berdasarkan pendidikan terakhir responden

Tabel 3

Kelompok Pendidikan Terakhir Responden

\begin{tabular}{|l|c|c|c|}
\hline No & Tingkat Pendidikan & Jumlah (orang) & Persentase \\
\hline 1 & SMA/K & 41 & $87 \%$ \\
\hline 2 & D3 & 3 & $7 \%$ \\
\hline 3 & S1 & 3 & $6 \%$ \\
\hline 4 & S2 & 0 & $0 \%$ \\
\hline 5 & S3 & 0 & $0 \%$ \\
\hline & Jumlah & $\mathbf{4 7}$ & $\mathbf{1 0 0 \%}$ \\
\hline
\end{tabular}

Sumber : Data kuesioner diolah, 2019 
d) Karakteristik responden berdasarkan jabatan pekerjaan responden

Tabel 4

Kelompok Jabatan Pekerjaan Responden

\begin{tabular}{|l|c|c|c|}
\hline No. & Tingkat Pendidikan & Jumlah (orang) & Persentase \\
\hline 1 & Pimpinan Perusahaan/Manager & 5 & $11 \%$ \\
\hline 2 & Staff/Karyawan & 42 & $89 \%$ \\
\hline & Jumlah & $\mathbf{4 7}$ & $\mathbf{1 0 0 \%}$ \\
\hline
\end{tabular}

Sumber : Data kuesioner diolah

e) Karakteristik responden berdasarkan lama bekerja responden

Tabel 5

Kelompok Lama Bekerja Responden

\begin{tabular}{|c|c|c|c|}
\hline No & Lama Bekerja (tahun) & Jumlah (orang) & Persentase \\
\hline 1 & $<1$ & 16 & $34 \%$ \\
\hline 2 & $1-5$ & 30 & $64 \%$ \\
\hline 3 & $6-10$ & 0 & $0 \%$ \\
\hline 4 & $11-15$ & 1 & $2 \%$ \\
\hline & Jumlah & $\mathbf{4 7}$ & $\mathbf{1 0 0 \%}$ \\
\hline
\end{tabular}

Sumber : Data kuesioner diolah, 2019

\section{Uji Validias}

Berdasarkan hasil uji validitas, variabel sistem informasi akuntansi (X) maupun kualitas laporan keuangan (Y) bahwa seluruh pernyataan tersebut memiliki korelasi di atas atau lebih besar rtabel yang telah ditetapkan yaitu sebesar 0,288. Jadi dapat disimpulkan bahwa 10 item pernyataan tersebut dikatakan memenuhi syarat validitas.

\section{Uji Reliabilitas}

Uji reliabilitas dalam penelitian ini menggunakan Cronbach's Alpha $(\alpha)$, dimana suatu instrumen dapat dinyatakan handal (reliable) bila $\alpha>0,60$. Dari 47 orang responden untuk 10 item pernyataan yang ada dalam sistem informasi akuntansi (X) maupunkualitas laporan keuangan (Y) masing-masing memiliki tingkat reliabilitas lebih besar dari 0,60, sehingga dapat disimpulkan bahwa sebanyak 10 pernyataan dalam variabel sistem informasi akuntansi tersebut sudah reliabel.

\section{Uji Hipotesis}

\section{Analisis Regresi Sederhana}

Dengan menggunakan SPSS 23, diperoleh hasil regresi sistem informasi akuntansi terhadap kualitas laporan keuangan seperti pada tabel di bawah ini:

Tabel 6

Hasil Output Variables Entered/Removed Variables Entered/Removed ${ }^{\mathrm{a}}$

\begin{tabular}{|l|l|l|l|}
\hline Model & \multicolumn{1}{|c|}{$\begin{array}{c}\text { Variables } \\
\text { Entered }\end{array}$} & $\begin{array}{c}\text { Variables } \\
\text { Removed }\end{array}$ & Method \\
\hline 1 & $\begin{array}{l}\text { Sistem } \\
\text { Informasi } \\
\text { Akuntansi }\end{array}$ & & Enter \\
\hline
\end{tabular}

a. Dependent Variable: Kualitas Laporan Keuangan

b. All requested variables entered.

Sumber : Data diolah, 2019 
Dari tabel 6 menjelaskan tentang variabel yang dimasukkan serta metode yang digunakan. Dalam penelitian ini, variabel yang dimasukkan adalah variabel sistem informasi akuntansi sebagai variabel independen dan kualitas laporan keuangan sebagai variabel dependen serta metode yang digunakan adalah metode enter.

Tabel 7

Hasil Output Model Summary

Model Summary

\begin{tabular}{|l|r|r|r|r|}
\hline Model & R & R Square & $\begin{array}{c}\text { Adjusted R } \\
\text { Square }\end{array}$ & $\begin{array}{c}\text { Std. Error of } \\
\text { the Estimate }\end{array}$ \\
\hline 1 & $.765^{\mathrm{a}}$ & .586 & .577 & 2.034 \\
\hline
\end{tabular}

a. Predictors: (Constant), Sistem Informasi Akuntansi

Sumber : Data Diolah, 2019

Dari tabel 7 menjelaskan besarnya nilai korelasi / hubungan (R) yaitu sebesar 0,765. Dari output tersebut diperoleh koefisien determinasi (R Square) sebesar 0,586, yang mengandung pengertian bahwa pengaruh variabel bebas (Sistem informasi akuntansi) terhadap variabel terikat (Kualitas laporan keuangan) adalah sebesar 58,6\%

Tabel 8

Hasil Output ANOVA

ANOVA $^{\mathrm{a}}$

\begin{tabular}{|ll|r|r|r|r|r|}
\hline \multicolumn{2}{|l|}{ Model } & \multicolumn{1}{|c|}{$\begin{array}{l}\text { Sum of } \\
\text { Squares }\end{array}$} & Df & Mean Square & F & Sig. \\
\hline 1 & Regression & 263.286 & 1 & 263.286 & 63.629 & $.000^{\circ}$ \\
& Residual & 186.203 & 45 & 4.138 & & \\
Total & 449.489 & 46 & & & \\
\hline
\end{tabular}

a. Dependent Variable: Kualitas Laporan Keuangan

b. Predictors: (Constant), Sistem Informasi Akuntansi

Sumber: Data diolah, 2019

Dari tabel 8 diketahui bahwa nilai $\mathrm{F}$ hitung $=63,629$ dengan tingkat signifikansi sebesar $0,000<0,05$, maka model regresi dapat dipakai untuk memprediksi variabel kualitas laporan keuangan atau dengan kata lain ada pengaruh variabel sistem informasi akuntansi (X) terhadap kualitas laporan keuangan (Y)

Tabel 9

Hasil Output Coefficients

Coefficients $^{\mathbf{a}}$

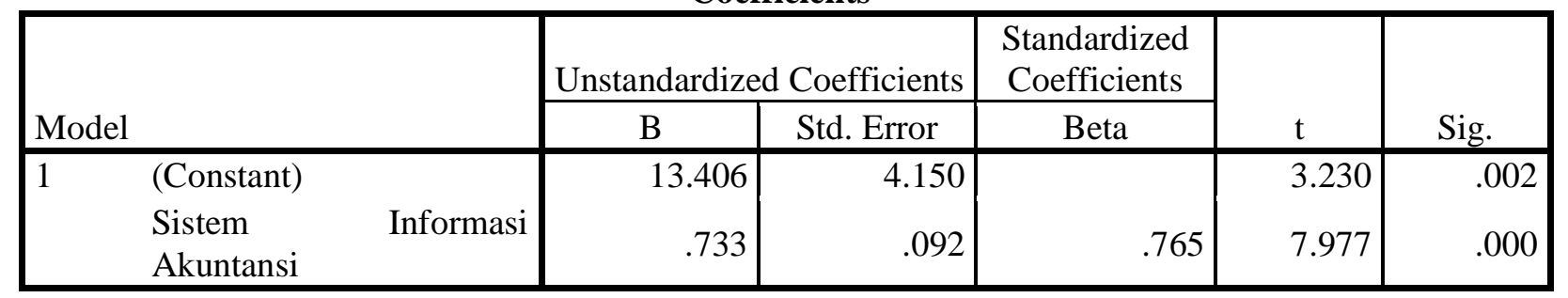

a. Dependent Variable: Kualitas Laporan Keuangan

Sumber : Data diolah, 2019 
Melalui hasil analisis regresi sederhana yang terdapat pada tabel 9, maka dapat dibentuk sebuah persamaan regresi sebagai berikut:

$\mathrm{Y}=\mathrm{a}+\mathrm{bX}$

$Y=13,406+0,733 X$

Dari Persamaan di atas maka dapat dijelaskan:

a) Konstanta (a) sebesar 13,406 berarti bahwa kualitas laporan keuangan tetap dapat meningkat sebesar nilai konstantanya meskipun sistem informasi akuntansi bernilai nol.

b) Koefisien X (sistem informasi akuntansi) bernilai positif sebesar 0,733, hal ini berarti setiap kenaikan satu skor untuk variabel sistem informasi akuntansi akan diikuti kenaikan kualitas laporan keuangan sebesar 0,733 dengan asumsi variabel lain konstan. Koefisien bernilai positif artinya sistem informasi akuntansi memberikan pengaruh yang positif. Semakin tinggi tingkat sistem informasi akuntansi, maka semakin tinggi juga tingkat kualitas laporan keuangan.

\section{Analisis Statistik Uji t}

Uji hipotesis dengan Uji t dilakukan dengan membandingkan antara thitung dengan ttabel. Untuk menentukan nilai ttabel ditentukan dengan tingkat signifikasi $0,05 / 2=0,025$ dengan derajat kebebasan $\mathrm{df}=(\mathrm{n}-\mathrm{k})$ atau 47-2 $=45$ dimana $\mathrm{n}$ adalah jumlah responden dan $\mathrm{k}$ adalah julmah variabel. Kriteria pengujian yang digunakan adalah:

a) Jika $t_{\text {hitung }}>t_{\text {tabel }}(\mathrm{n}-\mathrm{k})$ maka $\mathrm{H}$ diterima

b) Jika $t_{\text {hitung }}<t_{\text {tabel }}$ (n-k) maka H ditolak

Tabel 10

Hasil Uji t

Coefficients $^{\mathrm{a}}$

\begin{tabular}{|c|c|c|c|c|c|c|}
\hline \multirow[b]{2}{*}{ Model } & & \multicolumn{2}{|c|}{ Unstandardized Coefficients } & \multirow{2}{*}{$\begin{array}{c}\begin{array}{c}\text { Standardized } \\
\text { Coefficients }\end{array} \\
\text { Beta }\end{array}$} & \multirow[b]{2}{*}{$\mathrm{t}$} & \multirow[b]{2}{*}{ Sig. } \\
\hline & & B & Std. Error & & & \\
\hline 1 & (Constant) & 13.406 & 4.150 & & 3.230 & .002 \\
\hline & $\begin{array}{l}\text { Sistem Informasi } \\
\text { Akuntansi }\end{array}$ & .733 & .092 & .765 & 7.977 & .000 \\
\hline
\end{tabular}

a. Dependent Variable: Kualitas Laporan Keuangan

Sumber : Data diolah, 2019

Diketahui $t_{\text {tabel }}$ sebesar 2,026 dan dari pengujian berdasarkan uji t, diperoleh hasil $t_{\text {hitung }}>t_{\text {tabel }}$ yaitu 7,977 $>2,014$. Dilihat dari tingkat signifikansi, nilai signifikansi yang diperoleh yaitu 0,000 lebih kecil dari 0,05. Hal ini mengartikan bahwa adanya hubungan yang signifikansi antara sistem informasi akuntansi dan kualitas laporan keuangan sehingga sudah mendukung hipotesis, yaitu sistem informasi akuntansi berpengaruh positif terhadap kualitas laporan keuangan. 


\section{Uji Hipotesis Deskriptif}

Untuk mengetahui apakah sistem informasi akuntansi PT CSM Cargo telah berfungsi dengan baik atau tidak.

Tabel 11

Uji Variabel Sistem Informasi Akuntansi

\begin{tabular}{|c|c|c|c|c|c|c|}
\hline \multirow{2}{*}{ Pernyataan } & \multicolumn{7}{|c|}{ Jawaban } & \multirow{2}{*}{ Total } \\
\cline { 2 - 5 } & STS & TS & KS & S & SS & \\
\hline 1 & 0 & 0 & 0 & 23 & 24 & 47 \\
\hline 2 & 0 & 0 & 0 & 19 & 28 & 47 \\
\hline 3 & 0 & 0 & 1 & 23 & 23 & 47 \\
\hline 4 & 0 & 0 & 3 & 20 & 24 & 47 \\
\hline 5 & 0 & 0 & 0 & 16 & 31 & 47 \\
\hline 6 & 0 & 0 & 0 & 18 & 29 & 47 \\
\hline 7 & 0 & 0 & 0 & 21 & 26 & 47 \\
\hline 8 & 0 & 0 & 0 & 31 & 16 & 47 \\
\hline 9 & 0 & 0 & 0 & 19 & 28 & 47 \\
\hline 10 & 0 & 0 & 2 & 31 & 14 & 47 \\
\hline Total & 0 & 0 & 6 & 221 & 243 & 470 \\
\hline
\end{tabular}

Sumber : Data kuesioner diolah, 2019

Sesuai dengan tahapan pengujian dari tabel 11 maka ditemukan:

$$
\begin{gathered}
\text { Persentase }: \frac{\text { Total skor setuju dan sangat setuju }}{\text { Total skor }} \times 100 \% \\
\text { Persentase }: \frac{464}{470} \times 100 \%=98,7 \%
\end{gathered}
$$

Dari total skor setuju dan sangat setuju dibagi dengan total skor keseluruhan, dapat disimpulkan bahwa Sistem Informasi Akuntansi di PT CSM Cargo telah berfungsi dengan baik, dengan persentase sebesar 98,7 \% yaitu diantara 76\%- 100\% (berdasarkan Tabel Klasifikasi Sistem Informasi Akuntansi).

\section{Tabel 12}

\begin{tabular}{|c|c|c|c|c|c|c|}
\hline \multirow{2}{*}{ Pernyataan } & \multicolumn{5}{|c|}{ Jawaban } & \multirow{2}{*}{ Total } \\
\hline & STS & TS & KS & $\mathrm{S}$ & SS & \\
\hline 1 & 0 & 0 & 2 & 24 & 21 & 47 \\
\hline 2 & 0 & 0 & 0 & 17 & 30 & 47 \\
\hline 3 & 0 & 0 & 0 & 9 & 38 & 47 \\
\hline 4 & 0 & 0 & 0 & 13 & 34 & 47 \\
\hline 5 & 0 & 0 & 1 & 17 & 29 & 47 \\
\hline 6 & 0 & 0 & 0 & 14 & 33 & 47 \\
\hline 7 & 0 & 0 & 0 & 20 & 27 & 47 \\
\hline 8 & 0 & 0 & 1 & 16 & 30 & 47 \\
\hline 9 & 0 & 0 & 0 & 12 & 35 & 47 \\
\hline 10 & 0 & 0 & 0 & 18 & 29 & 47 \\
\hline Total & 0 & 0 & 4 & 160 & 306 & 470 \\
\hline
\end{tabular}

Uji Variabel Kualitas Laporan Keuangan

Sumber : Data kuesioner diolah, 2019 
Sesuai dengan tahapan pengujian dari tabel 12 maka ditemukan:

$$
\begin{gathered}
\text { Persentase : } \frac{\text { Total skor setuju dan sangat setuju }}{\text { Total skor }} \times 100 \% \\
\text { Persentase }: \frac{466}{470} \times 100 \%=99,1 \%
\end{gathered}
$$

Dari total skor setuju dan sangat setuju dibagi dengan total skor keseluruhan, dapat disimpulkan bahwa Kualitas Laporan Keuangan di PT CSM Cargo telah dinilai dengan baik, dengan persentase sebesar 99,1 \% yaitu diantara 76\%- 100\% (berdasarkan Klasifikasi Kualitas Laporan Keuangan).

\section{Analisis Deskriptif}

Dalam penelitian ini, jumlah karyawan perusahaan yang bekerja di bagian administrasi adalah 46 ditambah 1 pimpinan perusahaan sehingga total keseluruhan adalah 47 karyawan. Penelitian ini dilakukan pada periode bulan Juli - Agustus 2019. Variabel penelitian meliputi penerapan sistem informasi akuntansi dan kualitas laporan keuangan.

Deskriptif variabel dari 47 responden dalam penelitian dapat dilihat pada tablel berikut :

Tabel 13

Analisis Statistk Deskriptif Descriptive Statistics

\begin{tabular}{|lc|r|r|r|r|r|}
\hline & & N & Minimum & Maximum & Mean & Std. Deviation \\
\hline Sistem & Informasi & 47 & 40 & 50 & 45.04 & 3.263 \\
Akuntansi & Laporan & 47 & 40 & 50 & 46.43 & 3.126 \\
Kualitas & 47 & & & & \\
Keuangan & & & & & \\
Valid N (listwise) & & 47 & &
\end{tabular}

Sumber : Data diolah, 2019

Tabel 13 menunjukkan statistik dari variabel penelitian Berdasarkan tabel di atas, hasil analisis dengan menggunakan statistik deskriptif terhadap sistem informasi akuntansi menunjukkan nilai minimum sebesar 40, nilai maksimum sebesar 50, mean (rata-rata) sebesar 45,04 dengan standar deviasi sebesar 3,263. Selanjutnya hasil analisis dengan menggunakan statistik deskriptif terhadap variabel kualitas laporan keuangan menunjukkan nilai minimum sebesar 40, nilai maksimum sebesar 50, mean (rata-rata) sebesar 46,43 dengan standar deviasi sebesar 3,126. Berdasarkan tabel diatas dapat disimpulkan bahwa nilai rata-rata tertinggi berada pada variabel kualitas laporan keuangan yakni 46,43. sedangkan yang terendah adalah variabel sistem informasi akuntansi yaitu 45,04. Untuk standar deviasi tertinggi berada pada variabel sistem informasi akuntansi yaitu 3,263 dan yang terendah adalah kualitas laporan keuangan yaitu 3,126.

\section{PEMBAHASAN}

Dari penelitian yang dilakukan peneliti melalui kuesioner, diperoleh hasil bahwa PT CSM Cargo telah melaksanakan penerapan sistem informasi akuntansi yang baik karena keberadaan peralatan komputer, tersedia program untuk memproses informasi, terdapat aplikasi untuk memproses informasi, memiliki pakar ahli, karyawan yang mampu mengoperasikan sistem informasi, terdapat media penyimpanan data perusahaan serta dukungan jaringan internet yang memadai yang terangkum kedalam kuesioner sistem informasi akuntansi yang di uji hipotesis deskriptif, didapatkan total skor setuju dan sangat setuju dibagi dengan total skor 
keseluruhan, dapat disimpulkan bahwa penerapan sistem informasi akuntansi pada PT CSM Cargo telah berfungsi dengan baik dengan persentase 98,7\%.

Kualitas Laporan Keuangan pada PT CSM Cargo telah memiliki kualitas yang baik karena karakteristik dapat dipahami, relevan, keandalan, sertaa dapat dibandingkan terangkum kedalam kuesioner varibel kualitas laporan keuangan yang di uji hipotesis deskriptif, didapatkan total skor setuju dan sangat setuju dibagi dengan total skor keseluruhan, dapat disimpulkan bahwa kualitas laporan keuangan pada PT CSM Cargo telah berfungsi dengan baik dengan persentase $99,1 \%$.

Dari hasil analisis regresi dapat diketahui bahwa pengaruh penerapan sistem informasi akuntansi terhadap kualitas laporan keuangan adalah positif, dengan nilai koefisien sebesar 0,586, jadi sistem informasi akuntansi penerimaan kas dapat dipengaruhi secara signifikan oleh pengendalian intern dengan tingkat pengaruh sebesar 58,6\%. Jadi, 41,4\% berpengaruh diluar penelitian ini. Berdasarkan penelitian yang dilakukan peneliti melalui kuesioner, diperoleh hasil pengendalian intern berpengaruh signifikan terhadap kualitas laporan keuangan, hal ini dapat dilihat dari hasil uji t dimana variabel sistem informasi akuntansi diketahui ttabel sebesar 2,026 dan dari pengujian berdasarkan uji t, diperoleh hasil thitung $>$ ttabel yaitu 7,977 > 2,014. Dilihat dari tingkat signifikansi, nilai signifikansi yang diperoleh yaitu 0,000 lebih kecil dari 0,05. Hal ini mengartikan bahwa adanya hubungan yang signifikansi antara sistem informasi akuntansi dan kualitas laporan keuangan sehingga sudah mendukung hipotesis, yaitu sistem informasi akuntansi berpengaruh positif terhadap kualitas laporan keuangan. Dari output anova juga diketahui bahwa nilai $\mathrm{F}$ hitung $=63,629$ dengan tingkat signifikansi sebesar 0,000<0,05, maka model regresi dapat dipakai untuk memprediksi variabel kualitas laporan keuangan atau dengan kata lain ada pengaruh variabel sistem informasi akuntansi (X) terhadap kualitas laporan keuangan (Y). Hasil penelitian ini sesuai dengan peneliti sebelumnya yang dilakukan oleh Sujadijaya (2018) serta Almumtahanah dan Samukri (2019) yang menunjukkan bahwa system informasi akuntansi berpengaruh positif terhadap kualitas laporan keuangan. Hasil penelitian ini menunjukkan bahwa dengan diterapkannya sistem informasi akuntansi dengan baik dan benar maka dapat meningkatkan kualitas laporan keuangan perusahaan.

\section{PENUTUP}

Penelitian ini memiliki tujuan untuk mengetahui pengaruh penerapan sistem informasi akuntansi apakah berpengaruh positif dan signifikan terhadap kualitas laporan keuangan pada PT. CSM Cargo. Berdasarkan penelitian yang dilakukan atas pengaruh penerapan sistem informasi akuntansi terhadap kualitas laporan keuangan dapat disimpulkan bahwa PT CSM Cargo telah melaksanakan sistem informasi akuntansi dengan baik dan kualitas laporan keuangan pada PT CSM Cargo memiliki kualitas yang baik. Sistem informasi akuntansi berpengaruh positif dan signifikan terhadap kualitas laporan keuangan. Hasil penelitian ini menunjukkan bahwa dengan diterapkannya sistem informasi akuntansi dengan baik dan benar dapat meningkatkan kualitas laporan keuangan.

Berdasarkan hasil penelitian yang dilakukan atas pengaruh sistem informasi akuntansi terhadap kualitas laporan keuangan dapat dikemukakan saran sebagai bahan pertimbangan untuk perusahaan. Dalam menjalankan sistem informasi akuntansi di PT CSM Cargo sudah berjalan dengan baik namun sebagai saran perusahaan harus menerbitkan buku pedoman yang berhubungan dengan sistem informasi akuntansi dan dipublikasikan ke setiap cabang PT CSM Cargo yang ada. Perusahaan hendaknya secara rutin melakukan sosialisasi terkait petunjuk teknis sistem informasi akuntansi. Perusahaan perlu meningkatkan lagi kualitas dari pelaporan keuangan di setiab cabang yang ada. Selain itu PT CSM Cargo perlu meningkatkan kerjasama dan komunikasi yang baik dengan manajer perusahaan/manajemen, vendor eksternal dan semua yang berhubungan dengan unit kerja dalam satu entitas atau peruasahaan . Kerjasama antara manajerial/Pimpinan perusaahan dan unit kerja dapat meminimalisir resiko salah saji serta penurunan kualitas laporan keuangan yang timbul akibat kurangnya penerapan sistem informasi akuntansi terhadap kualitas laporan keuangan. 


\section{REFERENSI}

Azhar, S. (2013). Sistem Informasi Akuntansi. Bandung: Lingga Jaya

Almumtahanah, \& Samukri. (2019). Pengaruh Penerapan Sistem Informasi Akuntansi terhadap Kualitas Laporan Keuangan. Jurnal AKUNTANSI STIE Muhammadiyah Jakarta. Vol. 8. No. 2. Halaman 146-154

Fahmi, I. (2013). Analisis Laporan Keuangan. Bandung: Alfabeta

Gelinas, U., Dull, R. B. \& Wheeler, P. R. (2012). Accounting Information Systems, 9th ed. South Western Cengage Learning. 5191 Natorp Boulevard Mason, USA. P. 19

Ikatan Akuntansi Indonesia. PSAK No. 1 Tentang Laporan Keuangan- edisi revisi 2015. Penerbit Dewan Standar Akuntansi Keuangan: PT. Raja Grafindo

Ikatan Akuntansi Indonesia (2015). Standar Akuntansi Keuangan, Jakarta: IAI

Hemmatfar, M., Salehi, M., \& Bayat, M. (2010). Competitive Advantages and Strategic Information Systems. International Journal of Businnes and Management, 5(7), 158

Prasisca, J., Kharlina, R., \& Yunita, C. (2013). Pengaruh Penerapan Sistem Informasi Akuntansi Keuangan Terhadap Kualitas Laporan Keuangan Pada Koperasi Lister PT.PLN (Persero) Kota Palembang.STIE MDP.

Puspitawati. L., Anggadini, S. D. (2011). Sistem Informasi Akuntansi. Yogyakarta: Graha Ilmu.

Romney, M. B., Steinbart, P. J. (2009). Accounting Information Systems. USA: Cengage Learning.

Sumarsan, T. (2013). Sistem Pengendalian Manajemen: Konsep, Aplikasi, dan Pengukuran Kinerja. Jakarta Barat: Indeks.

Soudani, S. N. (2012). The Usefulness of an Accounting Information System for Effective Organizational Performance. International Journal of economics and Finance, 4(5), 136-145

Sugiyono (2012). Metode Penelitian Kuantitatif Kualitatif dan R\&D. Bandung: Alfabeta.

Sujadijaya, T. (2017). Pengaruh Penerapan Sistem Informasi Akuntansi terhadap Kualitas Laporan Keuangan (Studi pada PT KARETA API INDONESIA (Persero) Kota Bandung). Skripsi(S1) thesis, Fakultas Ekonomi dan Bisnis Unpas Bandung

Tampaty, M. (2017) Analisis Faktor - Faktor yang Mempengaruhi Kualitas Informasi Laporan Keuangan Pemerintah Daerah (Studi Kasus pada Satuan Kerja Perangkat Daerah Kabupaten Bondowoso). Journal of Undergraduate Thesis, Universitas Muhammadiyah jember.

Wati,L.N. (2018). Metodologi Penelitian Dan Terapan aplikasi SPSS, EVIEWS,SmartPLS, dan AMOS. Bandung: Mujahid Press. 